\title{
STUDI LUAS DAN SEBARAN LAHAN GAMBUT DI KABUPATEN KAMPAR PROVINSI RIAU
}

\section{STUDY ON AREA AND DISTRIBUTION OF PEATLAND IN KAMPAR REGENCY-RIAU PROVINCE}

\author{
Nana Sudiana \\ Pusat Teknologi Reduksi Risiko Bencana - BPPT \\ e-mail: nana.sudiana@bppt.go.id
}

\begin{abstract}
Kampar Regency has a peat land about 191,363 ha. About half of the area is thin peat, while the remainder varies from moderate peat to deep peat. Currently peat in Kampar regency has been managed for the cultivation area, both for food crops and plantation crops and HTI. The problem is that in Kabupaten Kampar there is no detailed data on the extent and distribution of peatland resources as a reference for the protection and management plan. The purpose of this study is to identify the extent and distribution of peatland in Kampar regency, Riau Province. The study concluded that Kampar Regency has 5 types of peatland, namely Sikladipanjang (SLP) 125,920.92 ha, Benjah Bekasih (BBK) 17,960,79 ha, Peat (GBT) 19,829,41 ha, Klaru (KLR) 9,120, 14 ha, and Mendawai (MDW) 18,532.15 ha. The distribution of peatland is based on the administrative location divided into 5 clusters of Peat Area: Siak Hulu (17,191,40 ha), Raja (63,290.70 ha), Kampar Kiri Hilir (8,162,05 ha), Mine (26,766.16 ha) and Tapung (75,953.11 ha).
\end{abstract}

Keyword: Peatland, Kampar Regency

\begin{abstract}
ABSTRAK
Kabupaten Kampar mempunyai potensi lahan gambut sekitar 191.363 ha. Sekitar separuh luasan merupakan gambut tipis, sedangkan sisanya bervariasi dari mulai gambut sedang hingga gambut dalam. Saat ini gambut di Kabupaten Kampar sudah dikelola untuk kawasan budidaya, baik untuk tanaman pangan maupun tanaman perkebunan dan HTI. Permasalahannya adalah di Kabupaten Kampar belum tersedianya data detil mengenai luas dan sebaran sumberdaya lahan gambut sebagai acuan rencana perlindungan dan pengelolaannya. Tujuan studi ini adalah identifikasi luas dan sebaran lahan gambut di Kabupaten Kampar, Provinsi Riau. Hasil studi menyimpulkan bahwa Kabupaten Kampar memiliki 5 (tujuh) tipe lahan gambut, yaitu Sikladipanjang (SLP) 125.920,92 ha, Benjah Bekasih (BBK) 17.960,79 ha, Gambut (GBT) 19.829,41 ha, Klaru (KLR) 9.120,14 ha, dan Mendawai (MDW) 18.532,15 ha. Sebaran lahan gambut tersebut berdasarkan lokasi administrasi dibagi menjadi 5 Klaster Kawasan Gambut yaitu: Siak Hulu (17.191,40 ha), Perhentian Raja (63.290,70 ha), Kampar Kiri Hilir (8.162,05 ha), Tambang $(26.766,16 \mathrm{ha})$ dan Tapung $(75.953,11 \mathrm{ha})$.
\end{abstract}

Katakunci: Lahan Gambut, Kabupaten Kampar

\section{PENDAHULUAN}

\subsection{Latar Belakang}

Kabupaten Kampar mempunyai potensi lahan gambut sekitar 191.363 ha. Sekitar separuh luasan merupakan gambut tipis, sedangkan sisanya bervariasi dari mulai gambut sedang hingga gambut dalam. Saat ini gambut di Kabupaten Kampar sudah dikelola untuk kawasan budidaya, baik untuk tanaman pangan maupun tanaman perkebunan dan $\mathrm{HTI}$. Sukses tidaknya pengelolaan lahan gambut untuk lahan budidaya sangat tergantung pada kondisi karakteristiknya serta penguasaan dan pemahaman sains tentang watak gambut. 
Seperti diketahui gambut tergolong tanah yang fragile, artinya tanah ini sangat rentan dan rapuh terhadap kondisi lingkungan. Gambut mempunyai watak kesuburan yang rendah, sehingga apabila akan dilakukan untuk budidaya pertanian perlu dilakukan

penyuburan terlebih dahulu serta pengelolaan tata-air yang baik. Gambut yang baik digunakan untuk lahan pertanian adalah yang tingkat kematangannya sudah lanjut (saprik), gambut dangkal dan dekat dengan dataran banjir sungai. Makin jauh letak gambut dari aliran sungai disenyalir gambut akan cenderung mempunyai tingkat ketebalan yang tingi (gambut dalam) serta tingkat kesuburannya rendah.

Selain potensi pemanfaatan untuk lahan pertanian, kawasan gambut berdasarkan karakteristiknya dan ekosistemnya dapat dimanfaatkan untuk suatu kegunaan lainnya. Konsep pemanfaatan gambut dengan pendekataan wise use adalah konsepsi pemafaatan gambut yang bijaksana dan berkelanjutan. Kawasan gambut dapat digunakan untuk lahan pertanian/kawasan budidaya, kawasan kehutanan (HTI), kawasan konservasi, kawasan yang diekploitasi untuk energi, dan industri (pupuk dan media tanam).

Dalam banyak hal, mengingat dengan alasan untuk ekstensifikasi pertanian dan alternativ lahan untuk pengembangan perkebunan dan $\mathrm{HTI}$, lahan gambut yang kemungkinan dapat berupa kubah (dome) dibuka dan digunakan untuk kawasan budidaya. Kanal yang mengupas/melewati dome ini bisa berakibat fatal, karena bisa over-drainage dan bisa menyebabkan terjadinya degradasi lahan gambut. Fenomena degradasi lahan gambut sudah sering dijumpai pada kawasan-kawasan gambut yang awalnya diproyeksikan untuk kawasan budidaya akhirnya lahan gambut terlantar dan mati suri (bongkor).

Permasalahannya adalah di Kabupaten Kampar belum tersedianya data detil mengenai luas dan sebaran sumberdaya lahan gambut.

\subsection{Tujuan}

Tujuan kajian ini adalah identifikasi luas dan sebaran sumberdaya lahan gambut di Kabupaten Kampar, Provinsi Riau.

\section{METODOLOGI}

\subsection{Lokasi Kajian}

Wilayah kajian meliputi sumberdaya gambut yang masuk ke dalam wilayah administrasi Kabupaten Kampar (Tabel 1). Kabupaten Kampar dengan luas lebih kurang 1.128.928 Ha merupakan daerah yang terletak antara $01^{\circ} 00^{\prime} 40^{\prime \prime}$ Lintang Utara sampai $00^{0} 27^{\prime} 00^{\prime \prime}$ Lintang Selatan dan $100^{0} 28^{\prime} 30^{\prime \prime}$ - 101014'30" Bujur Timur (Kabupaten Kampar Dalam Angka, 2016).

\section{Tabel 1. Wilayah Kecamatan di Kabupaten} Kampar

\begin{tabular}{|c|l|r|c|}
\hline No & \multicolumn{1}{|c|}{ Kecamatan } & Luas (Ha) & $\%$ \\
\hline 1 & Kampar Kiri & 91533 & 8.1 \\
\hline 2 & Kampar Kiri Hulu & 130125 & 11.5 \\
\hline 3 & Kampar Kiri Hilir & 75974 & 6.7 \\
\hline 4 & $\begin{array}{l}\text { Kampar Kiri } \\
\text { Tengah }\end{array}$ & 33059 & 2.9 \\
\hline 5 & Gunung Sahilan & 59797 & 5.3 \\
\hline 6 & XIII Koto Kampar & 140640 & 12.5 \\
\hline 7 & Bangkinang Barat & 15141 & 1.3 \\
\hline 8 & Salo & 20783 & 1.8 \\
\hline 9 & Tapung & 136597 & 12.1 \\
\hline 10 & Tapung Hulu & 116915 & 10.4 \\
\hline 11 & Tapung Hilir & 101356 & 9.0 \\
\hline 12 & Bangkinang & 17718 & 1.6 \\
\hline 13 & $\begin{array}{l}\text { Bangkinang } \\
\text { Seberang }\end{array}$ & 25350 & 2.2 \\
\hline 14 & Kampar & 13628 & 1.2 \\
\hline 15 & Kampar Timur & 17308 & 1.5 \\
\hline 16 & Rumbio Jaya & 7692 & 0.7 \\
\hline 17 & Kampar Utara & 7984 & 0.7 \\
\hline 18 & Tambang & 37194 & 3.3 \\
\hline 19 & Siak Hulu & 68980 & 6.1 \\
\hline 20 & Perhentian Raja & 11154 & 1.0 \\
\hline & Jumlah & 1128928 & 100.0 \\
\hline
\end{tabular}

\subsection{Metoda Pengumpulan Data}

Pengumpulan data dan informasi sekunder melalui kajian literatur, yaitu: data sebaran dan luas lahan gambut dari berbagai laporan, peta-peta : peta administrasi Kabupaten Kampar, Peta Rupa Bumi Indonesia, dan Peta Landsystem.

Pengumpulan data primer dilakukan melalui kegiatan survey lapangan untuk pengecekan lapangan terhadap sebaran lokasi dan batas-batas lahan gambut di lapangan sesuai hasil analisis pemetaan 


\subsection{Metoda Analisis Data}

Analisis data menggunakan analisis tabulasi dan analisis spasial menggunakan aplikasi analisis data spasial. Tahapan analisis yang dilakukan adalah:

1. Analisis spasial batas-batas administrasi Kabupatan Kampar;

2. Analisis spasial tipologi lahan gambut berdasarkan analisis peta landsystem;

3. Analisis sebaran lokasi lahan gambut berdasarkan posisi administrasi di Kabupaten Kampar;

4. Analisis tipologi lahan gambut berdasarkan tipe landsystem;

5. Analisis luasan berdasarkan setiap tipe lahan gambut.

\section{HASIL DAN PEMBAHASAN}

\subsection{Bentuk Lahan (Landform) Bercirikan Lahan Gambut}

Untuk mengetahui potensi gambut di Kabupaten Kampar, telah dilakukan identifikasi sistem lahan yang khas dan bercirikan lahan gambut. Identifikasi dilakukan dengan mengunakan peta Sistem Lahan Sumatra RePPProt (Regional

Physical Planning Programme for Transmigration) yang dibuat pada tahun 1988 dengan skala 1:250.000. Identifikasi diarahkan untuk mengenali bentuk lahan (landform) yang memiliki ciri lahan gambut di wilayah administrasi Kabupaten Kampar.

Ekosistem gambut di Pulau Sumatera dapat dijumpai di 5 tipe bentuk lahan (landform) yaitu pantai berpasir, rawa-rawa, dataran aluvial, lembah aluvial, dan terasteras. Pada 5 tipe bentuk lahan ini terdapat 9 jenis sistem lahan (land system), masingmasing memiliki tipologi ekosistem gambut yang khas. Diskripsi umum dari kesembilan sistem lahan tersebut dan bentuk lahannya disajikan pada Tabel 2.
Tabel 2. Tipologi Ekosistem Gambut Sumatra

\begin{tabular}{|c|c|c|c|c|}
\hline No & $\begin{array}{l}\text { Tipologi } \\
\text { Ekosistem }\end{array}$ & \multicolumn{2}{|c|}{ Sistem Lahan } & $\begin{array}{l}\text { Bentuk } \\
\text { Lahan }\end{array}$ \\
\hline 1 & $\begin{array}{l}\text { Rawa-rawa } \\
\text { gambut pada } \\
\text { pantai berpasir }\end{array}$ & $\begin{array}{l}\text { Banjar } \\
\text { Lawas }\end{array}$ & BLW & $\begin{array}{l}\text { Pantai } \\
\text { Berpasir }\end{array}$ \\
\hline 2 & $\begin{array}{l}\text { Dataran banjir } \\
\text { bergambut } \\
\text { tergenang } \\
\text { rawa } \\
\text { permanen }\end{array}$ & Klaru & $\mathrm{KLR}$ & $\begin{array}{l}\text { Rawa- } \\
\text { rawa }\end{array}$ \\
\hline 3 & $\begin{array}{l}\text { Dataran banjir } \\
\text { berawa } \\
\text { gambut di } \\
\text { lembah sempit }\end{array}$ & Beliti & $\mathrm{BLI}$ & \\
\hline 4 & $\begin{array}{l}\text { Rawa gambut } \\
\text { dangkal }\end{array}$ & Mendawai & MDW & \\
\hline 5 & $\begin{array}{l}\text { Rawa gambut } \\
\text { dalam, } \\
\text { permukaannya } \\
\text { berbentuk } \\
\text { kubah }\end{array}$ & Gambut & GBT & \\
\hline 6 & $\begin{array}{l}\text { Dataran } \\
\text { pertemuan } \\
\text { sungai-pantai } \\
\text { bergambut }\end{array}$ & Kahayan & $\mathrm{KHY}$ & \begin{tabular}{|l} 
Dataran \\
Aluvial
\end{tabular} \\
\hline 7 & $\begin{array}{l}\text { Dataran banjir } \\
\text { sungai di } \\
\text { perbukitan }\end{array}$ & Bakunan & $\overline{B K N}$ & \begin{tabular}{|l} 
Lembah \\
Aluvial
\end{tabular} \\
\hline 8 & $\begin{array}{l}\text { Teras-teras } \\
\text { laut tua } \\
\text { berawa } \\
\text { gambut }\end{array}$ & $\begin{array}{l}\text { Benjah } \\
\text { Bekasik }\end{array}$ & BBK & $\begin{array}{l}\text { Teras- } \\
\text { teras }\end{array}$ \\
\hline 9 & $\begin{array}{l}\text { Rawa gambut } \\
\text { di teras-teras } \\
\text { laut tua } \\
\text { berpasir dan } \\
\text { berliat }\end{array}$ & $\begin{array}{l}\text { Sikladi } \\
\text { panjang }\end{array}$ & SLP & \\
\hline
\end{tabular}

Sumber : RePPProT,1990

Selain bentuk lahan, setiap tipe ekosistem gambut memiliki ciri fisiografis yang khas yang membedakannya dari tipe ekosistem gambut yang lainnya. Ciri fisiografis semacam ini, untuk ke sembilan tipologi ekosistem gambut Pulau Sumatra, disajikan pada Tabel 3. 
Tabel 3. Tipologi dan Fisiografi Ekosistem Gambut Pulau Sumatra

\begin{tabular}{|c|c|}
\hline \multicolumn{2}{|c|}{ TIPOLOGI DAN PENAMPANG MELINTANG } \\
\hline \multirow{2}{*}{$\begin{array}{l}\text { Banjar } \\
\text { Lawas } \\
\text { (BLW) }\end{array}$} & Rawa-rawa gambut pada pantai berpasir \\
\hline & ${ }_{3 m}$ Sea $\quad$ BLW \\
\hline \multirow[t]{2}{*}{$\begin{array}{l}\text { Klaru } \\
\text { (KLR) }\end{array}$} & $\begin{array}{l}\text { Dataran banjir bergambut tergenang } \\
\text { permanen }\end{array}$ \\
\hline & 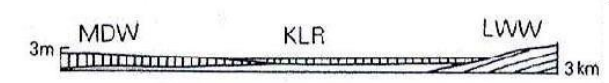 \\
\hline \multirow[t]{2}{*}{$\begin{array}{l}\text { Beliti } \\
\text { (BLI) }\end{array}$} & $\begin{array}{l}\text { Dataran banjir berawa gambut di lembah } \\
\text { sempit }\end{array}$ \\
\hline & LWW \\
\hline \multirow{2}{*}{$\begin{array}{l}\text { Menda- } \\
\text { wai } \\
\text { (MDW) }\end{array}$} & Rawa s \\
\hline & $\begin{array}{c}\text { MDW } \\
\text { 3m }\end{array}$ \\
\hline \multirow[t]{2}{*}{$\begin{array}{l}\text { Gambut } \\
\text { (GBT) }\end{array}$} & $\begin{array}{l}\text { Rawa gambut dalam, permukaannya } \\
\text { berbentuk kubah }\end{array}$ \\
\hline & ${ }^{\mathrm{GBT}}$ \\
\hline \multirow[b]{2}{*}{$\begin{array}{l}\text { Kahayan } \\
\text { (KHY) }\end{array}$} & Dataran pertemuan sungai-pantai bergambut \\
\hline & ${ }_{3 \mathrm{~m}}^{\mathrm{KHY}} \mathrm{MOW}_{3 \mathrm{~m}}$ \\
\hline \multirow[b]{2}{*}{$\begin{array}{l}\text { Bakunan } \\
\text { (BKN) }\end{array}$} & Dataran banjir sungai di perbukitan \\
\hline & ${ }^{10 m}=\frac{\text { BKN }}{\text { BWH }}$ \\
\hline \multirow{2}{*}{$\begin{array}{l}\text { Benjah } \\
\text { Bekasik } \\
\text { (BBK) }\end{array}$} & Teras-teras laut tua berawa gambut \\
\hline & 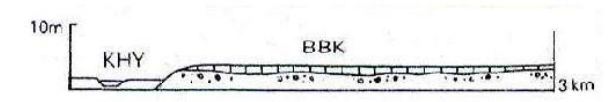 \\
\hline \multirow{2}{*}{$\begin{array}{l}\text { Sikladi } \\
\text { panjang } \\
\text { (SLP) }\end{array}$} & $\begin{array}{l}\text { Rawa gambut di teras-teras laut tua berpasir } \\
\text { dan berliat }\end{array}$ \\
\hline & ${ }^{10 \mathrm{~m}[\mathrm{KHY}}$ \\
\hline & Organic sediments - peat \\
\hline & 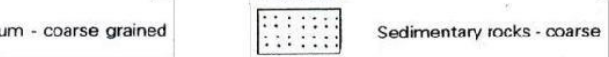 \\
\hline
\end{tabular}

Di wilayah administrasi Kabupaten Kampar dapat dijumpai 9 (sembilan) tipe bentuk lahan yaitu pegunungan, perbukitan, dataran, teras-teras, dataran alluvial, lembah alluvial, dataran dan meander alluvial, kipas dan lahar, dan rawa-rawa. Peta bentuk lahan dan penampang melintang arah Barat-Timur, disajikan dalam Gambar 1.

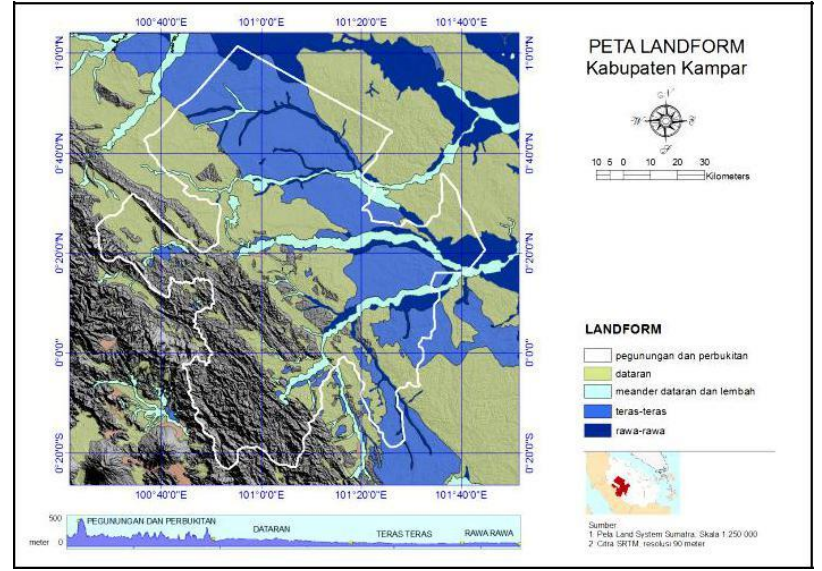

\section{Gambar 1. Peta Bentuk Lahan Kabupaten Kampar}

Peta Bentuk Lahan pada gambar di atas mengelompokan 9 tipologi bentuk lahan menjadi 6 kelompok bentuk lahan yaitu (1) pegunungan dan perbukitan, (2) dataran, (3) teras-teras, (4) rawa-rawa, (5) meander, dataran, dan lembah alluvial, dan (6) kipas alluvial dan lahar. Hasil analisis proporsi (presentase) luasan ke enam kelompok bentuk lahan ini dengan GIS yang disajikan pada Tabel 4 memberikan gambaran bahwa mayoritas (lebih dari 50\%) kelompok bentuk lahan di Wilayah Kabupaten Kampar adalah perbukitan dan pegunungan $(25.63 \%)$ dan dataran (32.50\%). Pada kedua kelompok mayoritas bentuk lahan yang pertama ini tidak dimungkinkan dijumpai ekosistem gambut.

Mayoritas kelompok bentuk lahan yang kedua adalah bentuk lahan teras-teras yang luasan proporsinya sekitar $28 \%$. Pada kelompok tipe bentuk lahan ini dimungkinkan dapat dijumpai 2 (dua) tipe ekosistem gambut yaitu Benjah Bekasih (BBK) dan Sikladipanjang (SLP).

Tiga kelompok tipe bentuk lahan terakhir, yaitu rawa-rawa, meander dataran dan lembah alluvial, dan kipas alluvial dan lahar merupakan bentuk lahan minoritas yang total luasannya sekitar $13 \%$. Namun demikian, di kelompok bentuk lahan minoritas ini dimungkinkan untuk dijumpai 5 tipe ekosistem gambut yaitu Klaru (KLR), Beliti (BLI), Mendawai (MDW), Gambut (GBT), Bakunan (BKN). 
Tabel 4. Analisis Proporsi (\%) Kelompok Bentuk Lahan Kabupaten Kampar

\begin{tabular}{|c|l|c|l|}
\hline No & Bentuk Lahan & $\begin{array}{c}\text { Proporsi } \\
(\%)\end{array}$ & $\begin{array}{l}\text { Tipe Lahan } \\
\text { Gambut }\end{array}$ \\
\hline 1 & $\begin{array}{l}\text { Pegunungan } \\
\text { dan } \\
\text { perbukitan }\end{array}$ & 25.63 & Tidak ada \\
\hline 2 & Dataran & 32.50 & Tidak ada \\
\hline 3 & Teras-teras & 28.24 & $\begin{array}{l}\text { Benjah } \\
\text { Bekasih } \\
\text { (BBK), } \\
\text { Sikladi } \\
\text { panjang(SLP) }\end{array}$ \\
\hline 4 & $\begin{array}{l}\text { Rawa-rawa } \\
\text { Klaru (KLR), } \\
\text { Beliti (BLI), } \\
\text { Mendawai } \\
\text { (MDW), } \\
\text { Gambut } \\
\text { (GBT) }\end{array}$ \\
\hline 5 & $\begin{array}{l}\text { Meander } \\
\text { dataran } \\
\text { aluvial dan } \\
\text { lembah } \\
\text { alluvial }\end{array}$ & 7.20 & $\begin{array}{l}\text { Bakunan } \\
\text { (BKN) }\end{array}$ \\
\hline 6 & $\begin{array}{l}\text { Kipas aluvial } \\
\text { dan lahar }\end{array}$ & 0.11 & Tidak ada \\
\hline
\end{tabular}

Sumber: Hasil Analisis

\subsection{Sistem Lahan}

Identifikasi ekosistem gambut di wilayah Kabupaten Kampar dilakukan berdasarkan kunci identifikasi pada Table 2 . dan analisis spasial dengan bantuan software GIS menggunakan peta Land System Sumatra lembar 0816, 0817, 0717, dan 0716 . Kemudian data tersebut dioverlay dengan peta administrasi Kabupaten Kampar dan citra DEM (digital elevation model) SRTM (Shuttle Radar Topographic Mission).

Hasil identifikasi menunjukkan bahwa di wilayah Kabupaten Kampar terdapat 7 (tujuh) tipe ekosistem gambut. Mayoritas luasannya dijumpai pada bentuk lahan teras-teras yaitu tipe Sikladipanjang (SLP) rawa-rawa gambut pada teras laut tua yang berpasir dan berliat dengan proporsi luasan mencapai $67 \%$. Lima tipe yang lain yaitu BBK (Benjah Bekasih), BKN (Bakunan), BLI (Beliti), GBT (Gambut), KLR (Klaru), dan MDW(Mendawai) dijumpai dalam proporsi luasan minoritas antara 3-7\%. Secara rinci tipologi dan luas ekosistem gambut di
Kabupaten Kampar disajikan pada Tabel 5.

Tabel 5. Analisis Proporsi (\%) Kelompok Bentuk Lahan Kabupaten Kampar

\begin{tabular}{|l|l|l|l|c|}
\hline No & $\begin{array}{l}\text { Sistem } \\
\text { Lahan }\end{array}$ & Kode & $\begin{array}{c}\text { Bentuk } \\
\text { Lahan }\end{array}$ & $\begin{array}{c}\text { Proporsi } \\
\text { Luasan } \\
(\%)\end{array}$ \\
\hline 1 & $\begin{array}{l}\text { Benjah } \\
\text { Bekasih }\end{array}$ & BBK & $\begin{array}{l}\text { Teras- } \\
\text { teras }\end{array}$ & 5.20 \\
\hline 2 & $\begin{array}{l}\text { Sikladi } \\
\text { panjang }\end{array}$ & SLP & $\begin{array}{l}\text { Teras- } \\
\text { teras }\end{array}$ & 66.91 \\
\hline 3 & Bakunan & BKN & $\begin{array}{l}\text { Lembah } \\
\text { Aluvial }\end{array}$ & 6.32 \\
\hline 4 & Beliti & BLI & Rawa-rawa & 6.69 \\
\hline 5 & Gambut & GBT & Rawa-rawa & 5.95 \\
\hline 6 & Klaru & KLR & Rawa-rawa & 3.72 \\
\hline 7 & Mendawai & MDW & Rawa-rawa & 5.20 \\
\hline
\end{tabular}

Sumber: Hasil Analisis

\subsection{Sebaran dan Luasan Kawasan Gambut}

Hasil analisis spasial yang telah diverifikasi melalui pengamatan lapangan menunjukkan bahwa lahan gambut di Kabupaten Kampar terdiri dari 5 (lima) sistem lahan, yaitu Benjah Bekasih (BBK), Sikladipnajang (SLP), Gambut (GBT), Klaru (KLR), Mendawai. Sebaran dan luasan kawasan gambut di Kabupaten Kampar dapat dilihat pada Tabel 6 . 
Tabel 6. Tipologi Ekosistem Gambut di Kabupaten Kampar

\begin{tabular}{|c|l|c|r|l|}
\hline No & $\begin{array}{l}\text { Sistem } \\
\text { Lahan }\end{array}$ & Luas (Ha) & $\%$ & Lokasi \\
\hline 1. & $\begin{array}{l}\text { Benjah } \\
\text { Bekasih } \\
\text { (BBK) }\end{array}$ & $17.960,79$ & 9,4 & $\begin{array}{l}\text { Kecamata } \\
\text { n } \\
\text { Tambang }\end{array}$ \\
\hline 2. & $\begin{array}{l}\text { Sikladi } \\
\text { panjang } \\
\text { (SLP) }\end{array}$ & $125.920,92$ & 65,8 & $\begin{array}{l}\text { Kecamata } \\
\text { n Tapung }\end{array}$ \\
\hline 3. & $\begin{array}{l}\text { Gambut } \\
\text { (GBT) }\end{array}$ & $19.829,41$ & 10,4 & $\begin{array}{l}\text { Kecamata } \\
\text { n Siak } \\
\text { Hulu dan } \\
\text { Kampar } \\
\text { Kiri Hilir }\end{array}$ \\
\hline 4. & $\begin{array}{l}\text { Klaru } \\
\text { (KLR) }\end{array}$ & $9.120,14$ & 4,8 & $\begin{array}{l}\text { Kecamata } \\
\text { n Siak } \\
\text { Hulu, } \\
\text { Kampar, } \\
\text { Kampai } \\
\text { Kiti } \\
\text { Tengah, } \\
\text { Gunung } \\
\text { Sahilan }\end{array}$ \\
\hline 5. & $\begin{array}{l}\text { Menda- } \\
\text { wai } \\
\text { (MDW) }\end{array}$ & $18.532,15$ & 9,7 & $\begin{array}{l}\text { Kecamata } \\
\text { Siak } \\
\text { Hulu dan } \\
\text { Kampar } \\
\text { Kiri Hilir }\end{array}$ \\
\hline & $\begin{array}{l}\text { Total } \\
191.363,41\end{array}$ & $\mathbf{1 0 0}$ & \\
\hline
\end{tabular}

Tabel tersebut di atas menunjukkan bahwa luasan lahan gambut yang paling besar adalah tipe system lahan SLP yaitu mencapai $125.920,92$ ha $(65,80 \%)$. Tipe SLP adalah lahan gambut yang sangat dangkal dengan kedalaman kurang dari 1 meter, seperti diuraikan pada sub bab terdahulu tipe ini merupakan gambut yang terbentuk diatas teras-teras laut tua berpasir dan berliat yang berbentuk datar. Tipe lahan gambut ini akan terus mengalami pengurangan dalam luas dan volumenya karena proses mineralisasi akibat pengaruh kegiatan pemanfaatan seperti perkebunan, pertanian, dan lainnya. Berdasarkan lokasinya tipe lahan gambut ini dominan tersebar Kecamatan Tapung.

Tipe gambut dalam (GBT) secara umum memiliki kedalaman di atas 3 meter $(>3 \mathrm{~m})$ seluas $19.829,41$ ha $(10,36 \%)$. Sebaran tipe lahan gambut ini meliputi Kecamatan Siak Hulu dan Kecamtan Kampar Kiri Hilir. Berasosiasi dengan tipe lahan gambut ini adalah tipe lahan gambut dangkal (MDW) yang secara umum memiliki kedalaman 1-3 meter. Luas tipe lahan gambut MDW mencapai 18.532,15 ha $(9,68 \%)$, tersebar di Kecamatan Siak Hulu dan Kampar Kiri Hilir.

Tipe gambut Benjah Bekasih (BBK) merupakan tipe lahan gambut yang unik yang dimiliki oleh Kabupaten Kampar, tipe ini hanya terdapat di wilayah ini di seluruh Indonesia. Dari hasil pengamatan dan pengukuran karakteristik fisiknya memang memiliki formasi tanah gambut yang berbeda dengan tipe lainnya. Secara detil karakteristik tersebut akan dibahas pada sub bab selanjutnya. Luasan tipe gambut ini adalah $17.960,79$ ha $(9,39 \%)$, yang lokasinya berada di Kecamatan Tambang dan Kecamatan Tapung.

Tipe lahan gambut terakhir adalah Klaru (KLR), merupakan lahan gambut ekosisem rawa-rawa yang selalu tergenang, biasanya berada di kiri dan kanan aliran sungai. Luas tipe lahan gambut ini mencapai $9.120,14$ ha $(4,77 \%)$. Lokasinya berada di wilayah administrasi kecamatan Kecamatan Perhentian Raja dan Tambang. Secara spasial disajikan pada Gambar 2.

\subsection{Klasterisasi Kawasan Gambut}

Klasterisasi kawasan gambut dilakukan atas dasar pertimbangan beberapa aspek yaitu aspek sebaran geografis, pola distribusi spatial, bentuk lahan (landform), batasan ekologis untuk mempermudah didalam analisis dan

penyusunan arahan perencanaan pengelolaannya.

Berdasarkan data hasil analisis dan pengamatan lapangan, maka di Kabupaten Kampar di bagi menjadi 5 (lima) kawasan gambut, yaitu Siak Hulu, Perhentian Raja, Kampar Kiri Hilir, Tambang, dan Tapung. Penamaan tersebut didasarkan kepada faktor dominasi wilayah administrasi kecamatan di dalam kawasan gambut tersebut.

Dari hasil analisis tersebut diperoleh sebaran dan luasan klaster seperti yang disajikan pada Gambar 2 dan Tabel 7. 


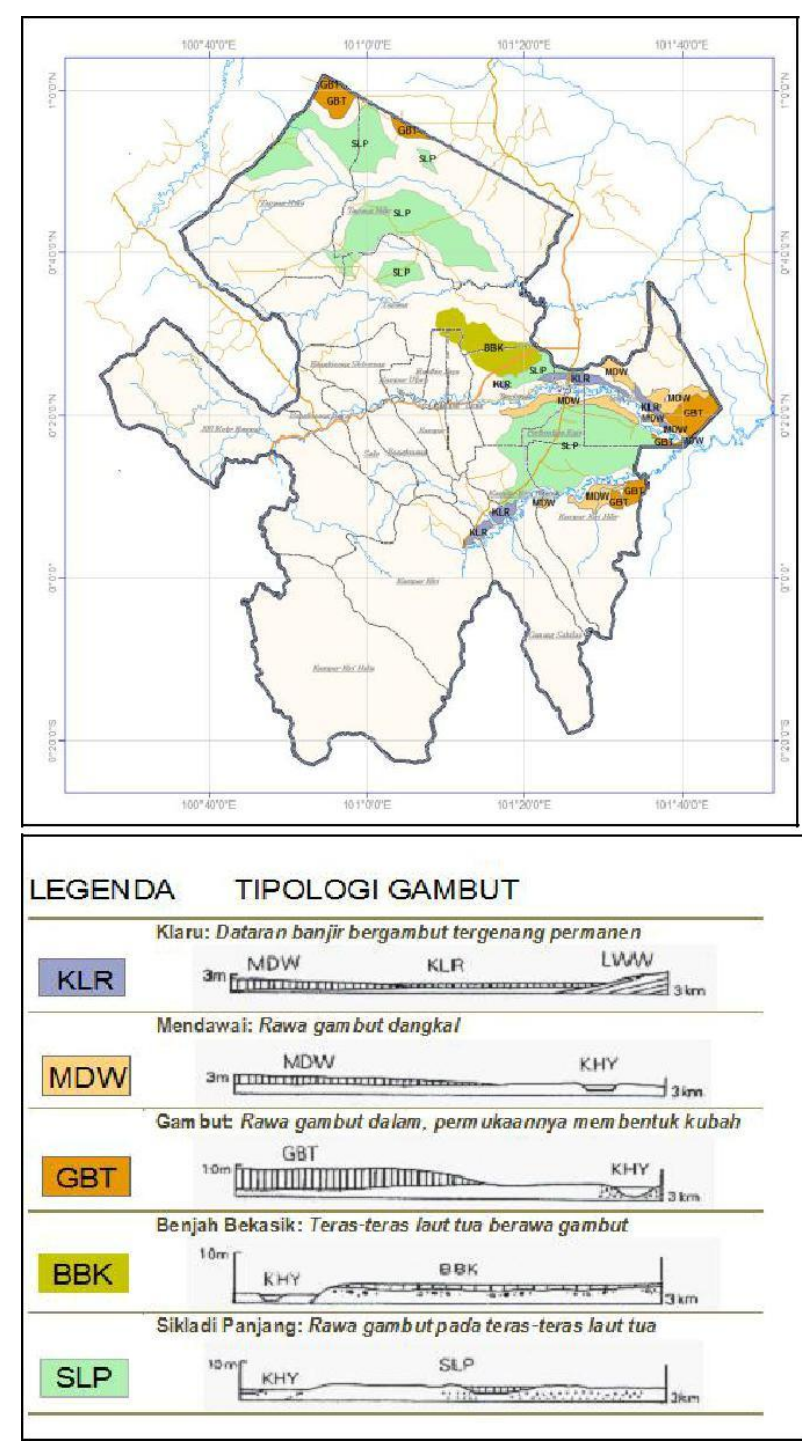

Gambar 2. Sebaran Klaster Kawasan Lahan Gambut di Kabupaten Kampar

Tabel 7. Tipologi Ekosistem Gambut di Kabupaten Kampar

\begin{tabular}{|l|l|r|r|}
\hline No & $\begin{array}{c}\text { Klaster } \\
\text { Kawasan } \\
\text { Gambut }\end{array}$ & $\begin{array}{c}\text { Luas Area } \\
\text { (Ha) }\end{array}$ & Proporsi \\
\hline 1 & Siak Hulu & $171.91,40$ & 8,98 \\
\hline 2 & Perhentian Raja & $63.290,70$ & 33,07 \\
\hline 3 & Kampar Kiri Hilir & $8.162,05$ & 4,27 \\
\hline 4 & Tambang & $26.766,16$ & 13,99 \\
\hline 5 & Tapung & $75.953,11$ & 39,69 \\
\hline \multicolumn{2}{|c|}{ Total } & $\mathbf{1 9 1 . 3 6 3 , 4 1}$ & $\mathbf{1 0 0 , 0 0}$ \\
\hline
\end{tabular}

\subsubsection{Kawasan Gambut Siak Hulu}

Kawasan gambut Siak Hulu secara administrasi berada di Wilayah Kecamatan Siak Hulu, sedangkan berdasarkan batas ekologi terletak disebelah utara pertemuan Sungai Kampar Kiri dan Kampar Kanan. Berdasarkan bentuk lahannya kawasan ini termasuk dalam kategori rawa-rawa dengan tipologi ekosistem gambut yang meliputi rawa gambut dangkal disebut MDW (Mendawai), rawa gambut dalam yang permukaannya berbentuk kubah disebut GBT (Gambut), Hasil analisis spasial luas klaster kawasan gambut tersebut mencapai $17.191,40$ ha, yang terdiri dari gambut dalam (GBT) seluas 7.359,23 Ha (42,81\%), dengan kedalaman puncak gambut mencapai $6,3 \mathrm{~m}$, areal gambut dangkal tipe MDW (kurang dari 3 meter) seluas 7.693,71 ha $(44,75 \%)$, dan gambut yang selalu tergenang seluas $2.138,457$ ha $(12,44 \%)$. Secara rinci luas kawasan gambut Siak Hulu dan tipe areal gambut didalamnya dapat dilihat pada Tabel 8 ..

Tabel 8. Luas Kawasan Gambut Siak Hulu di Kabupaten Kampar

\begin{tabular}{|c|l|c|c|}
\hline No & \multicolumn{1}{|c|}{$\begin{array}{c}\text { Tipe Lahan } \\
\text { Gambut }\end{array}$} & $\begin{array}{c}\text { Luas } \\
\text { (Ha) }\end{array}$ & $\begin{array}{c}\text { Proporsi } \\
(\%)\end{array}$ \\
\hline 1. & $\begin{array}{l}\text { Gambut dalam } \\
\text { (GBT) }\end{array}$ & $7.359,23$ & 42,81 \\
\hline 2. & $\begin{array}{l}\text { Gambut } \\
\text { tergenang (KLR) }\end{array}$ & $2.138,46$ & 12,44 \\
\hline 3. & $\begin{array}{l}\text { Gambut dangkal } \\
\text { (MDW) }\end{array}$ & $7.693,71$ & 44,75 \\
\hline \multicolumn{2}{|c|}{ Total } & $17.191,40$ & $\mathbf{1 0 0 , 0 0}$ \\
\hline
\end{tabular}

\subsubsection{Kawasan Gambut Perhentian Raja}

Kawasan Gambut Perhentian Raja secara administrasi berada di empat wilayah kecamatan, yaitu Kec. Perhentian Raja, Kec. Siak Hulu, Kec,. Tambang. Kec. Kampar Kiri Tengah, dan Kec. Kampar Kiri Hilir. Berdasarkan batas ekologis kawasan gambut ini terletak diapit oleh dua sungai besar yaitu Sungai Kampar Kiri dan Sungai Kampar Kanan mulai dari tengah sampai ke titik pertermuan kedua sungai tersebut menjadi Sungai Kampar. Bentuk lahan kawasan ini sebagian besar termasuk dalam kategori teras-teras dengan tipologi ekosistem berupa rawa gambut di terasteras laut tua berpasir dan berliat dengan 
system lahan dominan adalah SLP (Sikladipanjang). Bentuk lahan lainnya adalah rawa-rawa dengan tipologi ekosistem berupa rawa gambut dalam (GBT), gambut dangkal (MDW), dan sisitm lahan selalu tergenang (KLR). Hasil analisis spasial luas keseluruhan kawasan gambut Perhentian Raja adalah $63.290,70$ ha, yang terdiri dari areal gambut sangat dangkal (SLP) seluas $52.930,11$ ha $(83,63 \%)$, gambut dankal (MDW) seluas 6183,40 ha $(9,77 \%)$, dan gambut tergenang (KLR) seluas 3353,97 ha $(5,30 \%)$, dan gambut dalam (GBT) seluas 823,22 ha $(1,30 \%)$.

Secara rinci luas kawasan gambut Perhentian Raja dan tipe areal gambut didalamnya dapat dilihat pada Tabel 9.

Tabel 9. Luas Kawasan Gambut Perhentian Raja di Kabupaten Kampar

\begin{tabular}{|c|c|c|c|}
\hline No & $\begin{array}{c}\text { Tipe Lahan } \\
\text { Gambut }\end{array}$ & $\begin{array}{l}\text { Luas } \\
(\mathrm{Ha})\end{array}$ & $\begin{array}{c}\text { Propor } \\
\text { si } \\
(\%)\end{array}$ \\
\hline 1. & $\begin{array}{l}\text { Gambut } \\
\text { tergenang (SLP) }\end{array}$ & $52.930,108$ & 83,63 \\
\hline 2. & $\begin{array}{l}\text { Gambut dangkal } \\
\text { (MDW) }\end{array}$ & $6.183,403$ & 9,77 \\
\hline 3. & $\begin{array}{l}\text { Gambut } \\
\text { tergenang (KLR) }\end{array}$ & 3353,97 & 5,30 \\
\hline 4. & $\begin{array}{l}\text { Gambut dalam } \\
\text { (GBT) }\end{array}$ & 823,217 & 1,30 \\
\hline \multicolumn{2}{|r|}{ Total } & $63.290,698$ & 100,00 \\
\hline
\end{tabular}

\subsubsection{Kawasan Gambut Kampar Kiri hilir}

Kawasan gambut Kampar Kiri Hilir secara administrasi seluruhnya masuk ke dalam wilayah Kecamatan Kampar Kiri Hilir, sedangkan berdasarkan batas ekologi terletak di sebelah selatan Sungai Kampar Kiri yang merupakan rawa yang dibentuk oleh Sungai Dungun yang membelah kawasan ini dan bermuara di sungai Kampar Kiri. Bentuk lahannya merupakan rawa-rawa dengan tipologi ekosistem rawa gabungan dari dataran banjir berawa gambut di lembah sempit disebut sistim lahan BLI (Beliti), rawa gambut dangkal dengan sistim lahan MDW (Mendawai), dan rawa gambut dalam yang permukaannya berbentuk kubah disebut sistim lahan GBT (Gambut). Hasil analisis spasial luas kawasan gambut tersebut mencapai $8.162,05$ ha yang terdiri dari gambut dalam (GBT) seluas $3.507,01$
$\mathrm{Ha}(42,97 \%)$ dengan kedalaman gambut mencapai $6,7 \mathrm{~m}$, dan gambut dangkal (MDW) yaitu dengan kedalaman kurang dari 3 meter seluas $4.655,04$ ha $(57,03 \%)$. Secara rinci luas kawasan gambut Perhentian Raja dan tipe areal gambut didalamnya dapat dilihat pada Tabel 10 .

Tabel 10. Luas Kawasan Gambut Perhentian Raja di Kabupaten Kampar

\begin{tabular}{|c|l|c|r|}
\hline No & \multicolumn{1}{|c|}{$\begin{array}{c}\text { Tipe Lahan } \\
\text { Gambut }\end{array}$} & \multicolumn{1}{|c|}{$\begin{array}{c}\text { Luas } \\
\text { (Ha) }\end{array}$} & Proporsi \\
\hline 1. & $\begin{array}{l}\text { Gambut dalam } \\
\text { (GBT) }\end{array}$ & $3.507,01$ & 42,97 \\
\hline 2. & $\begin{array}{l}\text { Gambut dangkal } \\
\text { (MDW) }\end{array}$ & $4.655,04$ & 57,03 \\
\hline \multicolumn{2}{|c|}{ Total } & $\mathbf{8 . 1 6 2 , 0 5}$ & $\mathbf{1 0 0 , 0 0}$ \\
\hline
\end{tabular}

\subsubsection{Kawasan Gambut Tambang}

Kawasan gambut tambang secara administrasi masuk ke dalam wilayah Kecamatan Tambang, Kecamatan Tapung, dan Kecamatan Siak Hulu, sedangkan berdasarkan batas ekologis terletak diantara sungai Kampar kanan dan Sungai Tapung Kiri. Bentuk lahan kawasan gambut ini merupakan teras-teras dengan tipologi ekosistem gambut berupa teras-teras laut tua berawa gambut dengan sistim lahan BBK (Benjah Bekasik) dan rawa gambut di teras-teras laut tua berpasir dan berliat dengan sistim lahan SLP (Sikladipanjang), serta rawa-rawa dengan tipologi ekosistem gambut dataran banjir bergambut tergenang rawa permanen dengan sistim lahan KLR (Klaru). Kawasan gambut tambang dengan sistim lahan BBK (Benjah Bekasih) merupakan tipe lahan gambut yang khas dimana tipe sistim lahan ini tidak ada di tempat lain. Dan hasil pengamatan dan analisis laboratorium menunjukkan karakteristik yang khas. Hasil analisis spasial luas kawasan gambut Tambang tersebut mencapai 26.766,16 ha yang terdiri dari gambut khas (BBK) seluas 17.960,79 ha $(67,10 \%)$, gambut sangat dangkal (SLP) seluas 5.177,65 Ha (19,34\%), dan areal gambut tergenang (KLR) seluas 3.627,72 ha (13,55\%). Secara rinci luas kawasan gambut Tambang dan tipe areal gambut didalamnya dapat dilihat pada Tabel 11 . 
$\begin{array}{lr}\text { Tabel 11. Luas } & \text { Kawasan } \\ \text { Perhentian } & \text { Raja di Kabupaten } \\ \text { Kampar } & \end{array}$

\begin{tabular}{|c|l|c|c|}
\hline No & \multicolumn{1}{|c|}{$\begin{array}{c}\text { Tipe Lahan } \\
\text { Gambut }\end{array}$} & $\begin{array}{c}\text { Luas } \\
\mathbf{( H a )}\end{array}$ & $\begin{array}{c}\text { Proporsi } \\
(\%)\end{array}$ \\
\hline 1. & $\begin{array}{l}\text { Gambut } \\
\text { khas/unik (BBK) }\end{array}$ & $17.960,79$ & 67,10 \\
\hline 2. & $\begin{array}{l}\text { Gambut sangat } \\
\text { dangkal (SLP) }\end{array}$ & $5.177,65$ & 19,34 \\
\hline 3. & $\begin{array}{l}\text { Gambut } \\
\text { tergenang (KLR) }\end{array}$ & $3.627,72$ & 13,55 \\
\hline \multicolumn{2}{|c|}{ Total } & $\mathbf{2 6 . 7 6 6 , 1 6}$ & $\mathbf{1 0 0 , 0 0}$ \\
\hline
\end{tabular}

\subsubsection{Kawasan Gambut Tapung}

Kawasan gambut Tapung secara administrasi masuk ke dalam wilayah Kecamatan Tapung, Kecamatan Tapung Hulu, dan Kecamatan Tapung Hilir. Berdasarkan batas ekologis kawasan gambut ini terletak diantara sungai Tapung kiri dan Sungai Tapung Kanan dan sebagian di utara Sungai Tapung Kanan. Bentuk lahannya dominan merupakan teras-teras dengan tipologi ekosistem gambut berupa Rawa gambut di teras-teras laut tua berpasir dan berliat (SLP) dan gambut dalam (GBT). Catatan penting hasil pengamatan di lapangan untuk kawasan gambut di lokasi ini adalah terjadinya proses mineralisasi lahan gambut menjadi lahan mineral, artinya luas kawasan gambut ini terus mengalami penurunan. Berdasarkan hasil analisis spasial dan inputan data hasil lapangan luas kawasan gambut tapung memiliki luas sekitar 75.953,11 ha, terdiri dari gambut sangat dangkal (SLP) seluas 67.813,16 ha $(89,28 \%)$ dan gambut dalam seluas $8.139,95$ ha $(10,72 \%)$. Secara rinci luas kawasan gambut Tambang dan tipe areal gambut didalamnya dapat dilihat pada Tabel 12.

Tabel 12. Luas Kawasan Gambut Perhentian Raja di Kabupaten Kampar

\begin{tabular}{|c|l|c|r|}
\hline No & \multicolumn{1}{|c|}{$\begin{array}{c}\text { Tipe Lahan } \\
\text { Gambut }\end{array}$} & $\begin{array}{c}\text { Luas } \\
\text { (Ha) }\end{array}$ & $\begin{array}{c}\text { Proporsi } \\
\text { (\%) }\end{array}$ \\
\hline 1. & $\begin{array}{l}\text { Gambut } \\
\text { khas/unik (BBK) }\end{array}$ & $17.960,79$ & 67,10 \\
\hline 2. & $\begin{array}{l}\text { Gambut sangat } \\
\text { dangkal (SLP) }\end{array}$ & $5.177,65$ & 19,34 \\
\hline 3. & $\begin{array}{l}\text { Gambut } \\
\text { tergenang (KLR) }\end{array}$ & $3.627,72$ & 13,55 \\
\hline \multicolumn{2}{|c|}{ Total } & $\mathbf{2 6 . 7 6 6 , 1 6}$ & $\mathbf{1 0 0 , 0 0}$ \\
\hline
\end{tabular}

\section{KESIMPULAN}

Berdasarkan hasil analisis dan pembahasan di atas dapat disimpulkan:

1. Kabupaten Kampar memiliki 5 (tujuh) tipe lahan gambut, yaitu Sikladipanjang (SLP) 125.920,92 ha, Benjah Bekasih (BBK) $17.960,79$ ha, Gambut (GBT) 19.829,41 ha, Klaru (KLR) 9.120,14 ha, dan Mendawai (MDW) 18.532,15 ha.

2. Sebaran lahan gambut di Kabupaten Kampar berdasarkan lokasi administrasi dibagi menjadi 5 Klaster Kawasan Gambut yaitu: Siak Hulu (17.191,40 ha), Perhentian Raja (63.290,70 ha), Kampar Kiri Hilir (8.162,05 ha), Tambang (26.766,16 ha) dan Tapung (75.953,11 ha).

\section{DAFTAR PUSTAKA}

Badan Pusat Statistika. 2016.Kabupaten Kampar Dalam Angka 2016. Bangkinang.

Nurjanah S. et al. 2013. Identifikasi Lokasi Penanaman Kembali Ramin (Gonystylus bancanus Kurz) Di Hutan Rawa Gambut Sumatera Dan Kalimantan.

Pusat Penelitian dan Pengembangan Konservasi dan Rehabilitasi, Badan Penelitian dan Pengembangan Kehutanan. Bogor.

Regional Physical Planning Programme for Transmigration (RePPProT). 1990. Base On Regional Reviews of The Land Resources of Central Kalimantan (1985), Irian Jaya (1986), East with South Kalimantan (1987), West Kalimantan (1988), Sumatra (1988), Sulawesi (1988), Maluku with Nusa Tenggara (1989), and Java with Bali (1989). Land Resources Departement, National Resources Institut, Overseas Development Administration, Foreign and Commonwealth Office-Direktorat Bina Program, Direktorat Jenderal Penyiapan Permukiman Departemen Transmigrasi, Jakarta, IndonesiaNational Coordination Agency For Surveys and Mapping (Bakosurtanal).

Wahyunto et al. 2014. Peta Lahan Gambut Indonesia: Metode Pembuatan, Tingkat Keyakinan, Dan Penggunaan. 
Indonesian Center for Agricultural Land Resources Research and Development. Bogor. (https://www.researchgate.net/publicati on/293821145).

Wetland International. 2003. Peta Luas Sebaran Lahan Gambut Dan Kandungan Karbon Di Pulau Sumatera. Bogor. 